\title{
Re-activation of degraded nickel cermet anodes - Nano-particle formation via reverse current pulses
}

Hauch, Anne; Marchese, M.; Lanzini, A.; Graves, Christopher R.

Published in:

Journal of Power Sources

Link to article, DOI:

10.1016/j.jpowsour.2017.11.088

Publication date:

2018

Document Version

Peer reviewed version

Link back to DTU Orbit

Citation (APA):

Hauch, A., Marchese, M., Lanzini, A., \& Graves, C. R. (2018). Re-activation of degraded nickel cermet anodes Nano-particle formation via reverse current pulses. Journal of Power Sources, 377, 110-120.

https://doi.org/10.1016/j.jpowsour.2017.11.088

\section{General rights}

Copyright and moral rights for the publications made accessible in the public portal are retained by the authors and/or other copyright owners and it is a condition of accessing publications that users recognise and abide by the legal requirements associated with these rights.

- Users may download and print one copy of any publication from the public portal for the purpose of private study or research.

- You may not further distribute the material or use it for any profit-making activity or commercial gain

- You may freely distribute the URL identifying the publication in the public portal 


\title{
Re-activation of degraded nickel cermet anodes
}

\section{- Nano-particle formation via reverse current pulses}

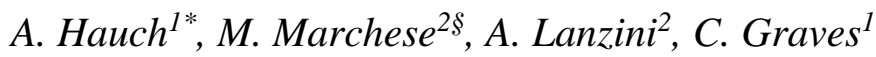 \\ ${ }^{1}$ Department of Energy Conversion and Storage, Technical University of Denmark, \\ Risф Campus, Frederiksborgvej 399, DK-4000 Roskilde, Denmark. \\ ${ }^{2}$ Department of Energy Technology, Politecnico di Torino, Corso Duca degli Abruzzi 24, \\ 10129, Torino, Italy. \\ * Corresponding author. Tel.: +4521362836. \\ E-mail: $\underline{\text { hauc@dtu.dk }}$
}

\footnotetext{
$\S$ The majority of the experimental work was conducted by M. Marchese.
} 


\begin{abstract}
The Ni/yttria-stabilized-zirconia (YSZ) cermet is the most commonly applied fuel electrode for solid oxide cells (SOCs). Loss of Ni/YSZ electrode activity is a key life-time limiting factor of the SOC. Developing means to mitigate this loss of performance or re-activate a fuel electrode is therefore important.

In this work, we report a series of five tests on state-of-the-art Ni/YSZ-YSZ-CGO barrierLSC/CGO cells. All cells were deliberately degraded via gas stream impurities in $\mathrm{CO}_{2} / \mathrm{CO}$ or harsh steam electrolysis operation. The cells were re-activated via a variety of reverse current treatments (RCTs). Via electrochemical impedance spectroscopy, we found that the Ni/YSZ electrode performance could be recovered via RCT, but not via constant fuel cell operation. For optimized RCT, we obtained a lower Ni/YSZ electrode resistance than the initial resistance. E.g. at $700^{\circ} \mathrm{C}$ we measured fuel electrode resistance of $180 \mathrm{~m} \Omega \cdot \mathrm{cm}^{2}, 390 \mathrm{~m} \Omega \cdot \mathrm{cm}^{2}$, and 159 $\mathrm{m} \Omega \cdot \mathrm{cm}^{2}$ before degradation, after degradation and after re-activation via RCT, respectively. Post-test SEM revealed that the RCT led to formation of nano-particles in the fuel electrode. Besides the remarkable improvement, the results also showed that RCTs can weaken Ni/YSZ interfaces and the electrode/electrolyte interface. This indicates that finding an optimum RCT profile is crucial for achieving maximum benefit.
\end{abstract}

\title{
Keywords
}

Solid Oxide Fuel Cells, reverse current treatment, Ni/YSZ electrode, microstructure, electrochemical impedance spectroscopy, activation 


\section{Introduction}

Reversible solid oxide cells (SOCs) have the potential to become an important energy conversion technology in the rapidly developing energy grid, which is accommodating a growing share of intermittent renewable electricity. SOCs can be applied as solid oxide fuel cells (SOFCs) for efficient and flexible electricity generation from chemical energy stored in fuels such as hydrogen, natural gas or biogas. In times of surplus of electrical energy from renewable sources such as wind and solar, the reversible SOC can be used as solid oxide electrolysis cells (SOECs) for storage of energy [1]. The SOEC then produces fuels such as hydrogen when the SOECs are used for steam electrolysis, or syn-gas when they are used for electrolysis of carbon dioxide and steam $\left(\mathrm{CO}_{2}+\mathrm{H}_{2} \mathrm{O}\right)$ [2]. Subsequently, synthetic natural gas or other synthetic fuels can be produced from the syn-gas via well-known catalytic processes [3-6].

By far most of the technological interesting SOC systems rely on cells applying Ni/yttriastabilized-zirconia (YSZ) based fuel electrodes $[7,8]$. These electrodes have the advantage of using abundant materials and up-scalable ceramic processing such as multilayer tape casting to produce high performing SOC [9]. These electrodes are therefore employed already for commercially available SOC products. Furthermore, it is required that the Ni/YSZ electrode keeps its high electrochemical performance. In cases where a degradation of the Ni/YSZ electrode has occurred (e.g., due to impurities in the gas stream [11-14]), it will be attractive to be able to recover the electrode performance. A method for improving the fuel electrode performance is via impregnation of electro-catalytically active nano-particles $[15,16]$, a practice which can also be done on already operated SOC stacks [17]. However, this method has the disadvantage that it sets requirements regarding the structure for infiltration. 
Furthermore, it can be challenging to ensure that the impregnated nano-particles are positioned optimally in the electrode structure to provide largest increase in triple phase boundary (TPB). An alternative solution is to apply in-situ - or even operando - methods that generate new nano-structures in the electrode and thereby new TPB sites for the electrochemical reaction in the existing electrode structure. Instead of introducing nano-particles in the electrode structure via infiltration, previous work has also elaborated on the possibility of generating nanoparticles via short shift between fuel cell and electrolysis operation of the SOC [18-20]. In the case of a Ni/YSZ-based electrode, a short shift from fuel cell operation to electrolysis and back could lead to partial reduction of the stabilized $\mathrm{ZrO}_{2}$ at electrochemical active sites. Depending on the conditions, this reverse current treatment (RCT) facilitates intimate reaction of the reduced stabilized $\mathrm{ZrO}_{2}$ with Ni. Subsequent re-oxidization yields nanostructured TPB regions. The in-operando generated nano-particles provide increased electrochemical performance. Initial experimental work has been reported on RCT on small scale Ni/YSZ electrodes [19,21] and more explorative electrolyte supported button-cells based on LCNT/ScSZ/LSM-ScSZ [20].

In this work, we focus on the application of larger scale technological relevant SOC. We investigate the possibilities for increasing the electrochemical performance via RCT for deliberately degraded Ni/YSZ electrodes, but also investigate the limitations of the RCT method. This is attained by exploring the effects of numbers of RCT cycles and of increasing time and increasing current density during the RCT cycles. Additionally we investigate whether a similar Ni/YSZ electrode improvement could have been obtained via constant galvanostatic fuel cell operation of the cell. 


\section{Experimental}

\subsection{Cell Specifications and Test Set-up}

The cells are Ni/YSZ supported Ni/YSZ-YSZ-CGO barrier-LSC/CGO (lanthanum-strontiumcobaltite and gadolinium-doped-ceria) based cells produced at DTU Energy, Ris $\varnothing$ Campus [9]. An overview of cell and test specifications is given in Table 1 . The cells comprises of a $\sim 10$ $\mu \mathrm{m}$ thick Ni/YSZ fuel electrode with a $\sim 300 \mu \mathrm{m}$ thick Ni/YSZ support layer, a $\sim 15 \mu \mathrm{m}$ thick YSZ electrolyte, a $2 \mu \mathrm{m}$ thick CGO barrier layer and a $\sim 40 \mu \mathrm{m}$ thick LSC/CGO oxygen electrode and $\sim 30 \mu \mathrm{m}$ thick LSC contact layer [22]. Zirconia stabilized with 8 mole percent $\mathrm{Y}_{2} \mathrm{O}_{3}$ was used for the electrolyte and the active fuel electrode layers. Zirconia stabilized with 3 mole percent $\mathrm{Y}_{2} \mathrm{O}_{3}$ was used for the support layer. For all applied $\mathrm{Ni} / \mathrm{YSZ}$ cermets the quantities of $\mathrm{NiO}$ and $\mathrm{YSZ}$ were scaled to provide a $\mathrm{Ni} / \mathrm{YSZ}$ volume ratio of 40/60 after reduction of $\mathrm{NiO}$. The active fuel electrode was produced as dense as possible leading to a pore fraction of approximately $22 \%$ after $\mathrm{NiO}$ reduction. For the production of the support layer, active fuel electrode and electrolyte layer successive tape casting i.e. a multilayer tape casting (MTC) process and lamination process was applied [9]. The three MTC layers of the tape were cut into $16 \times 16 \mathrm{~cm}^{2}$ pieces and co-sintered at $1315{ }^{\circ} \mathrm{C}$ [23]. Then the $\mathrm{CGO}$ barrier layer was applied by pulsed vapor deposition (PVD) and then cut into $53 \times 53 \mathrm{~mm}^{2}$ cells. The oxygen electrodes $\left(40 \times 40 \mathrm{~mm}^{2}\right)$ and LSC contact layers were applied by screen-printing. For cell $\mathrm{C}$ the oxygen electrode and contact layer was masked during screen printing to an area of only $4 \mathrm{x}$ $0.6 \mathrm{~cm}^{2}$ to accommodate reverse current treatment at higher current density. All tested cells reported in this work originated from the same casted tapes, barrier layer was added by PVD in one go for all cells and are therefore referred to as "sister cells". The set-up for single cell testing was illustrated and described in detail previously $[11,24]$, and a set-up close to the one 
illustrated as "Cell assembly 2" in the work by Ebbesen and co-workers was applied. However gold seals on anode side and seal less cathode assembly [11].

\subsection{Test Procedure and reverse current treatment (RCT)}

The cells were heated $\left(1{ }^{\circ} \mathrm{C} / \mathrm{min}\right)$ to $850{ }^{\circ} \mathrm{C}$ for sealing. The $\mathrm{NiO}$ was then reduced by leading $20 \mathrm{l} / \mathrm{h}$ of dry $9 \% \mathrm{H}_{2}$ in $\mathrm{N}_{2}$ to the fuel electrode for 1 hour followed by 2 hours of $20 \mathrm{l} / \mathrm{h}$ dry $\mathrm{H}_{2}$ to the fuel electrode while air was led to the oxygen electrode. Hereafter performance characterization via iV-curves and electrochemical impedance spectroscopy (EIS) was conducted. EIS was conducted both at different temperatures, gas compositions and at OCV and under current load. The Ni/YSZ electrodes were then deliberately degraded and subsequently the RCT was conducted as specified in Table 1. This is further illustrated in supplementary material (Figure S1). During the RCT EIS were recorded first at OCV and during fuel cell operation (air to the oxygen electrode, 4 and $20 \% \mathrm{H}_{2} \mathrm{O}$ in $\mathrm{H}_{2}$ to the fuel electrode). To keep the time at FC test conditions short during the RCT, the EIS recorded at 1 A. $\mathrm{cm}^{-2}$ only lasted 8 minutes and were recorded down to $2 \mathrm{~Hz}$. RCT were done via a direct switch from $1 \mathrm{~A} \cdot \mathrm{cm}^{-2}$ to $-1 \mathrm{~A} \cdot \mathrm{cm}^{-2}$. During the fast switch between fuel cell and electrolysis cell operation of the cells, the gas composition to the fuel electrode was kept at $4 \% \mathrm{H}_{2} \mathrm{O}$ in $\mathrm{H}_{2}$. The cell voltage was logged at a rate of 2-3 measurements per second. Cell voltages reached approximately 2.1 volts during each 10 seconds RCT. For Cell C even higher voltage was measured during the electrolysis shift (see supplementary material, Figure S1). 
Table 1: Test specifications for Cell A, B, C, D and E. Operation in fuel cell mode and electrolysis mode is abbreviated "FC" and "EL", respectively. The fuel electrode was supplied with $4 \% \mathrm{H}_{2} \mathrm{O}$ in $\mathrm{H}_{2}$ during switch from fuel cell operation to electrolysis operation and back to fuel cell operation i.e. during RCT. The fuel electrode was supplied with $20 \% \mathrm{H}_{2} \mathrm{O}$ in $\mathrm{H}_{2}$ during recording of EIS prior to and right after each RCT.

\begin{tabular}{|c|c|c|c|}
\hline Name & $\begin{array}{l}\text { Degradation } \\
\text { treatment }\end{array}$ & Reverse current treatment (RCT) & Test specific notes \\
\hline Cell A & $\begin{array}{l}\text { FC and EL iV-curves } \\
\text { at } 800 \mathrm{C}^{\circ} \text { in impure } \\
\mathrm{CO} / \mathrm{CO}_{2} \text { (flow for } \\
\text { both } \mathrm{iV} \text {-curves: } 12 \\
\mathrm{l} \cdot \mathrm{h}^{-1} / 6 \mathrm{l} \cdot \mathrm{h}^{-1} \text { ) }\end{array}$ & $\begin{array}{l}\text { Cycles of: } \\
\rightarrow 1 \mathrm{~h} \mathrm{OCV}(\mathrm{EIS}) \\
\rightarrow 10 \mathrm{~min} \text { FC at } 1 \mathrm{~A} \cdot \mathrm{cm}^{-2} \text { (EIS) } \\
\rightarrow 10 \mathrm{~s} \mathrm{EL} \mathrm{at}-1 \mathrm{~A} \cdot \mathrm{cm}^{-2} \\
\rightarrow 10 \mathrm{~min} \mathrm{FC} \text { at } 1 \mathrm{~A} \cdot \mathrm{cm}^{-2} \text { (EIS) } \\
\text { Return to OCV and new cycle }\end{array}$ & \\
\hline Cell B & $\begin{array}{l}\text { Fuel cell mode and } \\
\text { electrolysis mode } \mathrm{iV} \text { - } \\
\text { curves at } 800 \mathrm{C}^{\circ} \text { in } \\
\text { impure } \mathrm{CO} / \mathrm{CO}_{2} \text { (flow } \\
\text { for both } \mathrm{iV} \text {-curves: } \\
12 \mathrm{l} \cdot \mathrm{h}^{-1} / 6 \mathrm{l} \cdot \mathrm{h}^{-1} \text { ) }\end{array}$ & $\begin{array}{l}\text { Cycles of: } \\
\rightarrow 1 \mathrm{~h} \mathrm{OCV} \text { (EIS) } \\
\rightarrow 10 \mathrm{~min} \text { FC at } 1 \mathrm{~A} \cdot \mathrm{cm}^{-2} \text { (EIS) } \\
\rightarrow 10 \mathrm{~s} \mathrm{EL} \mathrm{at}-1 \mathrm{~A} \cdot \mathrm{cm}^{-2} \\
\rightarrow 10 \mathrm{~min} \text { FC at } 1 \mathrm{~A} \cdot \mathrm{cm}^{-2} \text { (EIS) } \\
\text { Return to OCV. New cycle with } 20 \mathrm{~s} \\
\text { EL and so forth until } 50 \mathrm{~s} \text { of EL at }-1 \\
\mathrm{~A} / \mathrm{cm}^{2} .\end{array}$ & $\begin{array}{l}\text { Test similar to test } \mathrm{A} \text {. } \\
\text { Investigating effect of time at EL } \\
\text { operation during RCT }\end{array}$ \\
\hline Cell C & $\begin{array}{l}\text { Fuel cell mode and } \\
\text { electrolysis mode } \mathrm{iV} \text { - } \\
\text { curves at } 800 \mathrm{C}^{\circ} \text { in } \\
\text { impure } \mathrm{CO} / \mathrm{CO}_{2} \text { (flow }\end{array}$ & $\begin{array}{l}\text { Cycles of: } \\
\rightarrow 1 \mathrm{~h} \mathrm{OCV}(\text { EIS }) \\
\rightarrow 10 \mathrm{~min} \text { FC at } 0.5 \mathrm{~A} \cdot \mathrm{cm}^{-2} \text { (EIS) } \\
\rightarrow 10 \mathrm{~s} \mathrm{EL} \mathrm{at}-0.5 \mathrm{~A} \cdot \mathrm{cm}^{-2}\end{array}$ & $\begin{array}{l}\text { Test similar to test A. } \\
\text { Investigating effect of current } \\
\text { density at EL operation during } \\
\text { RCT }\end{array}$ \\
\hline
\end{tabular}




\begin{tabular}{|c|c|c|c|}
\hline & $\begin{array}{l}\text { for both iV-curves: } \\
\left.121 \cdot h^{-1} / 61 \cdot h^{-1}\right)\end{array}$ & $\begin{array}{l}\rightarrow 10 \mathrm{~min} \mathrm{FC} \text { at } 0.5 \mathrm{~A} \cdot \mathrm{cm}^{-2}(\mathrm{EIS}) \\
\text { Return to OCV. New cycle with } \pm 1, \\
\text { then } \pm 2 \text { and } \pm 3 \mathrm{~A} \cdot \mathrm{cm}^{-2}\end{array}$ & \\
\hline Cell D & $\begin{array}{l}\text { Fuel cell mode and } \\
\text { electrolysis mode } \mathrm{iV} \text { - } \\
\text { curves at } 800 \mathrm{C}^{\circ} \text { in } \\
\text { impure } \mathrm{CO} / \mathrm{CO}_{2} \text { (flow } \\
\text { for both } \mathrm{iV} \text {-curves: } \\
12 \mathrm{l} \cdot \mathrm{h}^{-1} / 6 \mathrm{l} \cdot \mathrm{h}^{-1} \text { ) }\end{array}$ & $\begin{array}{l}\text { Operating in constant FC mode at } 1 \\
\mathrm{~A} / \mathrm{cm}^{2}\end{array}$ & $\begin{array}{l}\text { FC conditions as during the RCT } \\
\text { cycles of test A, B and C. Not } \\
\text { RCT. }\end{array}$ \\
\hline Cell E & $\begin{array}{l}\text { Harsh } \mathrm{H}_{2} \mathrm{O} \\
\text { electrolysis operation } \\
\text { (iV curves up to } 1580 \\
\mathrm{mV} \text { ) }\end{array}$ & $\begin{array}{l}\text { Cycles of: } \\
\rightarrow 1 \mathrm{~h} \mathrm{OCV}(\mathrm{EIS}) \\
\rightarrow 10 \mathrm{~min} \mathrm{FC} \text { at } 1 \mathrm{~A} \cdot \mathrm{cm}^{-2} \text { (EIS) } \\
\rightarrow 10 \mathrm{~s} \mathrm{EL} \mathrm{at}-1 \mathrm{~A} \cdot \mathrm{cm}^{-2} \\
\rightarrow 10 \mathrm{~min} \mathrm{FC} \text { at } 1 \mathrm{~A} \cdot \mathrm{cm}^{-2} \text { (EIS) } \\
\text { Return to OCV and new cycle }\end{array}$ & $\begin{array}{l}\text { Different type of degradation (no } \\
\mathrm{CO} / \mathrm{CO}_{2} \text { operation) but } \mathrm{RCT} \\
\text { treatment as for test } \mathrm{A}\end{array}$ \\
\hline
\end{tabular}

\subsection{Electrochemical Impedance Spectroscopy (EIS)}

A Solartron 1255 frequency analyzer was used for recording EIS both at OCV and under current load applying a set-up as described by Jensen [25]. Impedance spectra (IS) were recorded with 12 points/decade from $97 \mathrm{kHz}$ to $0.1 \mathrm{~Hz}$ during initial characterization and down to $2 \mathrm{~Hz}$ during RCT. In-house developed Python-based software was used for plotting and analysis of the impedance data [26]. In this work, experimentally obtained IS are depicted as inductance corrected data in Nyquist and Bode plots. Furthermore, plots of distribution of relaxation times (DRT) are provided. The DRT plots are used to illustrate and highlight frequency ranges for different processes contributing to the total impedance response [27,28]. To enable a quantitative analysis of the IS complex-non-linear-least-squares (CNLS) method was used to fit an equivalent circuit model to the impedance data. For a quantitative break- 
down of losses via IS the equivalent circuit based on the work reported by Kromp et al. [29] and the work by Ramos and others [30] was used. Table 2 provides an overview of the different resistance contributions included in the equivalent circuit model for impedance analysis and their interpretation. The electrochemical impedance response from the Ni/YSZ electrode was approximated by two RQ-elements. The higher frequency impedance arc (RQ) ionic at $\sim 10-25$ $\mathrm{kHz}$ has previously been ascribed to ionic transport through the ionic conducting matrix in the electrodes. For the applied cells (Ni/YSZ-YSZ-LSC/CGO) with the mixed ionic electronic and highly conducting LSC based oxygen electrode, the majority of the resistance $\mathrm{R}_{\text {ionic }}$ can be

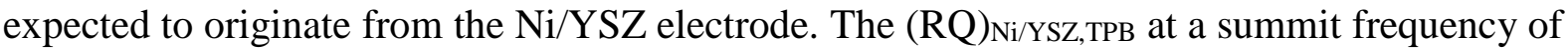
$\sim 1-15 \mathrm{kHz}$ is ascribed to the charge transfer reaction at the triple phase boundaries (TPBs). These two contributions to the overall impedance of the cell can also be described using a transmission line model (TLM) [28,31,32]. In the "Supplementary Material" a comparison of the application of the two models is given (see Figure S2). The impedance response from the LSC/CGO oxygen electrode has been approximated by a Gerisher-type response [22]; having a characteristic frequency of $\sim 300 \mathrm{~Hz}$. Furthermore; gas diffusion and gas conversion resistance contributions have been approximated by two RQ-circuits having characteristic frequencies around $\sim 50 \mathrm{~Hz}$ and $\sim 5 \mathrm{~Hz}$, respectively [33,34].

Table 2: Overview of resistance contributions included in the break-down of losses via equivalent circuit modeling of EIS and their physical interpretation [22,29,33,34].

\begin{tabular}{l|l}
\hline Resistance & Description \\
\hline $\mathrm{R}_{\mathrm{S}}$ & Ohmic resistance originating from electrolyte and contact components \\
\hline $\mathrm{R}_{\mathrm{ionic}}$ & Ion transport in the fuel electrode \\
\hline $\mathrm{R}_{\mathrm{Ni} / \mathrm{YSZ}, \mathrm{TPB}}$ & TPB reaction resistance in the fuel electrode (electrochemical reactions) \\
\hline
\end{tabular}




\begin{tabular}{l|l}
\hline $\mathrm{R}_{\text {fuel electr. }}$ & Total fuel electrode resistance: $\mathrm{R}_{\text {fuel. electr. }}=\mathrm{R}_{\text {ion }}+\mathrm{R}_{\mathrm{TPB}}$ \\
\hline $\mathrm{R}_{\mathrm{LSC} / \mathrm{CGO}}$ & Total oxygen electrode resistance: transport of species and electrochemical \\
& reactions \\
\hline $\mathrm{R}_{\text {Gas diff. }}$ & Resistance due to gas diffusion \\
\hline $\mathrm{R}_{\text {Gas conv. }}$ & Resistance due to gas conversion \\
\hline
\end{tabular}

\subsection{SEM imaging}

Pieces of a cross section length of $\sim 1 \mathrm{~cm}$ of all cells were prepared for SEM investigations by vacuum embedding in epoxy (EpoFix from Struers ${ }^{\circledR}$ ) followed by grinding and polishing. Three pieces were embedded from each tested cell; 1) a piece from the fuel inlet part of the cell, 2) a piece from the fuel outlet part of the cell and 3) a "reference" piece taken from the edge of the cell on which there was no oxygen electrode printed. The "reference" pieces have therefore not been subjected to any current treatment. A Zeiss Supra 35 FE-SEM (Field Emission Gun Scanning Electron Microscope) was used for imaging. SEM images were obtained at 8-10 kV using the secondary electron detector.

$\mathrm{Ni}$ and YSZ can be distinguished by simple visual inspection of the images where the "soft" Ni particles have scratches from sample preparation, which is not the case instead for the "hard" YSZ. Visually, Ni particles look like they are on top of the YSZ-backbone. This is a result of the slight bright rim contrast around the Ni particles, which is also used in the image analysis software for distinguishing Ni and YSZ by chromatic contrast. Energy dispersive spectroscopy (EDS) was performed on selected samples to confirm the image observations.

Furthermore, low-voltage SEM images were obtained at $0.9 \mathrm{kV}$ using the in-lens detector. Low-voltage in-lens SEM imaging allows percolating and non-percolating $\mathrm{Ni}$ to be distinguished in the Ni/YSZ cermet, as described by Thydén et al. [35]. 


\section{Results}

\subsection{Initial electrochemical performance}

All cells were subjected to the same initial characterization after reduction of $\mathrm{NiO}$ at $850{ }^{\circ} \mathrm{C}$. The very first IS recorded at OCV feeding air to the oxygen electrode and $4 \% \mathrm{H}_{2} \mathrm{O}$ in $\mathrm{H}_{2}$ to the fuel electrode were used to verify that the sister cells had identical initial performance (see "Supplementary material", Figure S3). The recorded IS verify that the cells coming from the same production batch are alike leading to essentially identical impedance response. Furthermore, this verifies that there are no major set-up related issues that could lead to systematic erroneous interpretation of data (improper contacting or sealing). Cell $\mathrm{C}$ cannot be compared directly with cell A, B, D and E due to the different masking of the oxygen electrode. This led to slight set-up changes and therefore changed gas flow patterns and less well-defined electrode area.

\subsection{Effect of degradation treatments}

Figure 1 shows IS recorded before and immediately after the intended degradation treatments. For cell A, B, C and D this was obtained via iV-curves in fuel cell and electrolysis mode while feeding an impure $\mathrm{CO} / \mathrm{CO}_{2}$ mixture [14]. For cell $\mathrm{E}$ degradation was obtained via iV-curves in harsh steam electrolysis conditions; up to $1580 \mathrm{mV}$ [36]. All five cells exhibit fuel electrode degradation as intended. The observed increase of the impedance of the cells consistently has a summit in the frequency range 1-10 kHz. This corresponds to the characteristic frequency for charge transfer reaction resistance at the TPB of the Ni/YSZ based fuel electrode; see also Figure 3 [37-39]. Cell B has slightly higher performance than cells A and D after degradation treatment. However, the relative increase in fuel electrode resistance upon degradation 
treatment is similar for the three cells. Furthermore, the IS in Figure 1 show that polarization resistances attributed to the oxygen electrode, gas diffusion and gas conversion were not visibly affected by the induced degradation treatment. The degradation treatment with the electrochemical performance loss (Figure 1) thereby represents a cell degraded by impurities, carbon deposition or harsh electrolysis conditions; all possible degradation mechanisms for SOC.
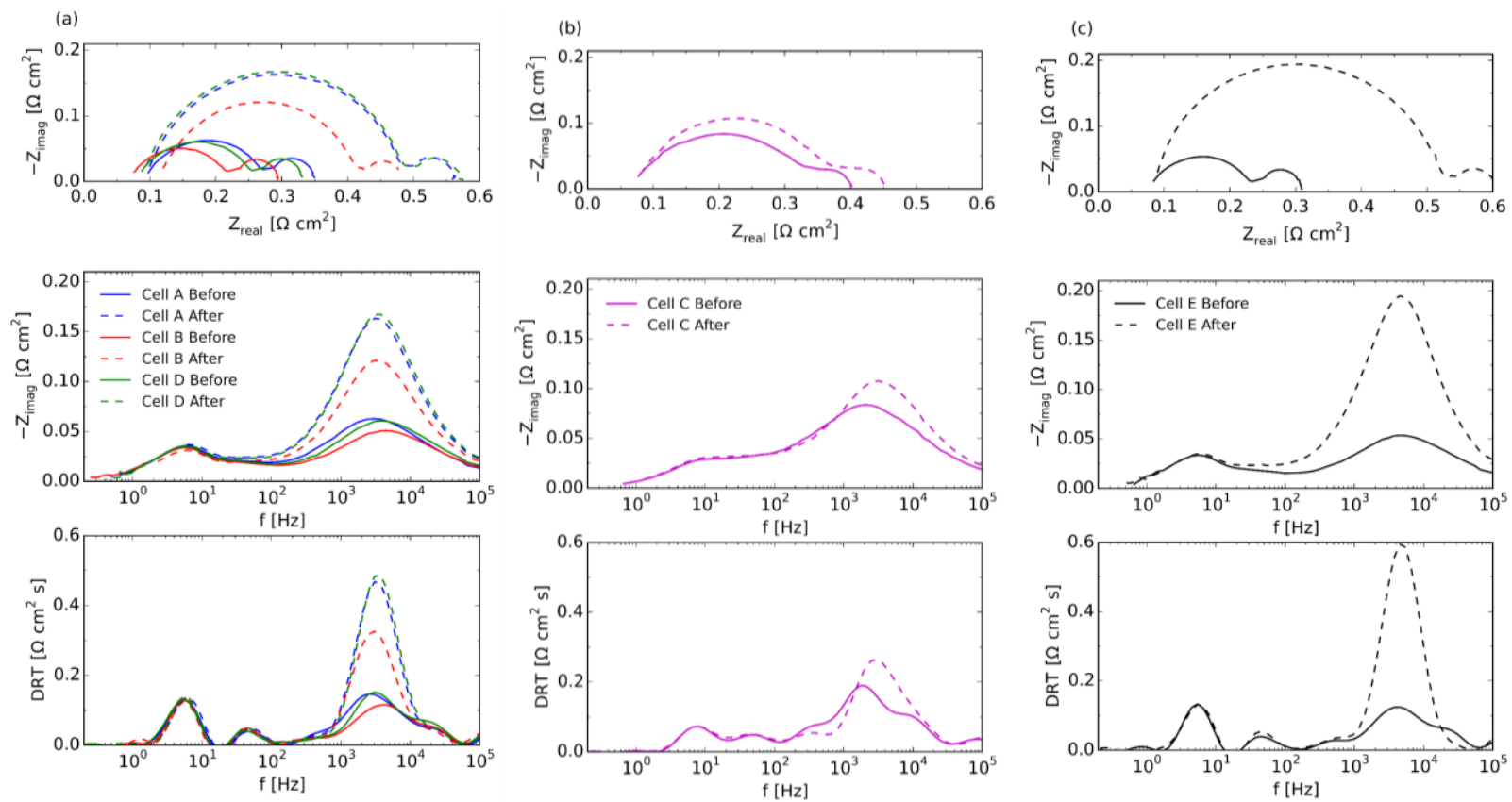

Figure 1: IS recorded at $700{ }^{\circ} \mathrm{C}, 20 \% \mathrm{H}_{2} \mathrm{O}$ in $\mathrm{H}_{2}$, air, $\mathrm{OCV}$, before and immediately after degradation.

a) For cell $\mathrm{A}, \mathrm{B}$ and $\mathrm{D}$ (sister cells, same cell geometry, same intended $\mathrm{CO} / \mathrm{CO}_{2}$ degradation treatment and b) cell $\mathrm{C}$ with same $\mathrm{CO} / \mathrm{CO}_{2}$ degradation treatment but not sister cell to $\mathrm{A}, \mathrm{B}$ and $\mathrm{D}$ and different test set-up geometry and c) IS for cell E, immediately before and after degradation via harsh electrolysis treatment (iV-curve). 


\subsection{Activation of Ni/YSZ electrode performance by reverse current treatment (RCT)}

After degradation of the cells, RCT according to the specifications in Table 1 were applied. IS were recorded at $\mathrm{OCV}$ and $700{ }^{\circ} \mathrm{C}$ applying 4 and $20 \% \mathrm{H}_{2} \mathrm{O}$ in $\mathrm{H}_{2}$ to the fuel electrode after each RCT or $100 \mathrm{~h}$ of constant galvanostatic fuel cell operation for Cell D. The spectra applying $20 \% \mathrm{H}_{2} \mathrm{O}$ in $\mathrm{H}_{2}$ are depicted in Figure 2 for cell A, B, C and D. We observed only limited fuel electrode re-activation upon constant fuel electrode operation. In fact, for cell D IS after degradation treatment and upon attempted re-activation via constant galvanostatic fuel cell operation produced a very modest performance recovery as shown in Figure 2d. This is in line with the limited cell voltage increase from 775 to $787 \mathrm{mV}$. From the IS recorded during RCT (Figure 2) it is clear that the common trends for the impedance of the cells is a significant decrease in the impedance originating from the fuel electrode. Upon RCT, this polarization resistance contribution decreases in magnitude while the corresponding summit frequency increases. During all RCT sequences depicted (Figure 2), an increase in the ohmic resistance for each RCT can be observed, as preliminarily reported previously [21], but not observed in other studies [19]. Cell E was degraded differently, but the RCT treatment was conducted as for Cell A. As evident from Table 3 and Figure 4 the re-activation of fuel electrode for Cell E followed exact same trends as for Cell A both with respect to fuel electrode resistances and summit frequencies. Cell E re-activation is therefore omitted in Figure 2.

To verify that it is the fuel electrode that degrades during the initial degradation and the fuel electrode that improves in performance as an effect of RCT (i.e. impedance increase and decrease) analysis of differences in impedance spectra (ADIS, [40]) was performed. The gas shift ADIS was performed before and after degradation, and before and after RCT by varying fuel electrode gas composition between $4 \%$ and $20 \% \mathrm{H}_{2} \mathrm{O}$ in $\mathrm{H}_{2}$. The results of the ADIS analysis are given in Figure 3. It is evident that the fuel electrode is affected both by the intended degradation via $\mathrm{iV}$-curves in $\mathrm{CO} / \mathrm{CO}_{2}$ mixture (Figure $3 \mathrm{a}$ ) and by harsh conditions for 
steam electrolysis operation (Figure $3 b$ ). From Figure $3 \mathrm{c}$ it is clear that the impedance response in the frequency range $1-10 \mathrm{kHz}$ can be attributed to the fuel electrode. Furthermore, there seem to be a tendency for the summit frequency to shift towards higher frequency as a result of RCT. These ADIS findings cannot be used to quantify the effect of degradation and re-activation of the fuel electrodes, but the ADIS analysis verifies that the impedance increase and decrease depicted in Figure 2 can be correctly attributed to impedance changes originating from the fuel electrode. 
(a)
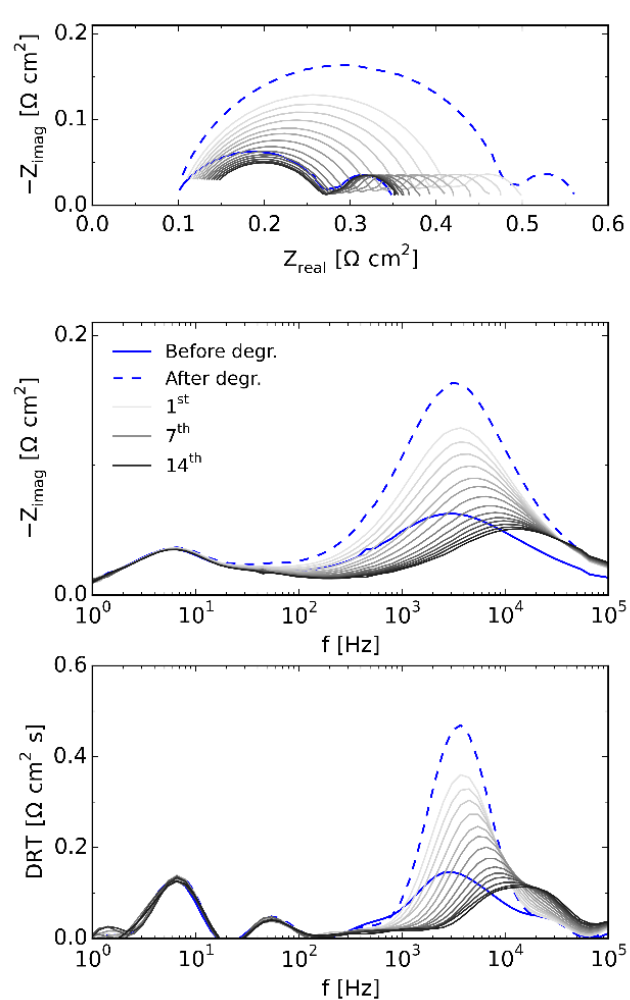

(c)
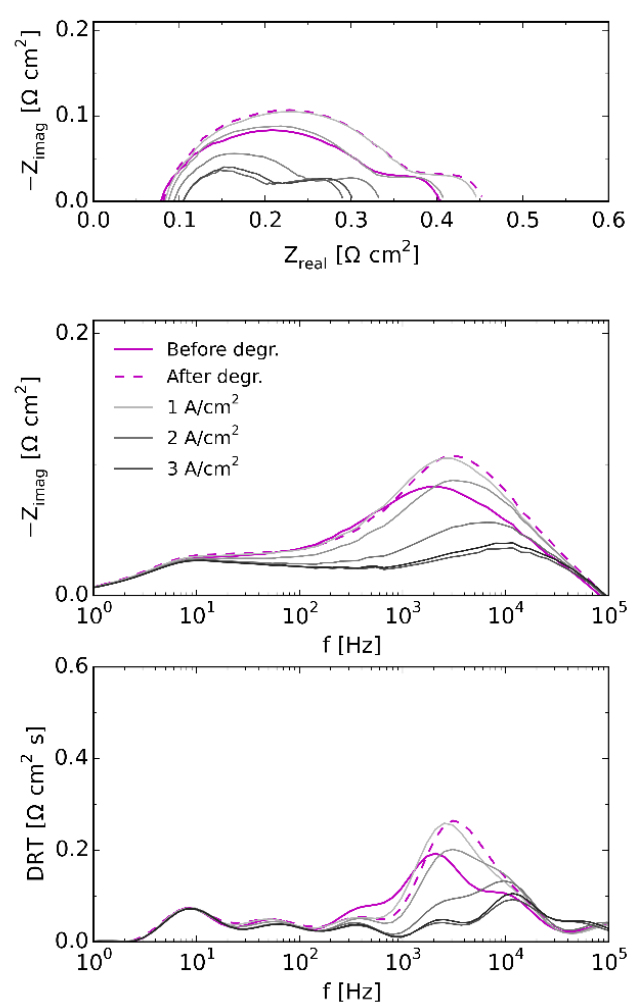

(b)
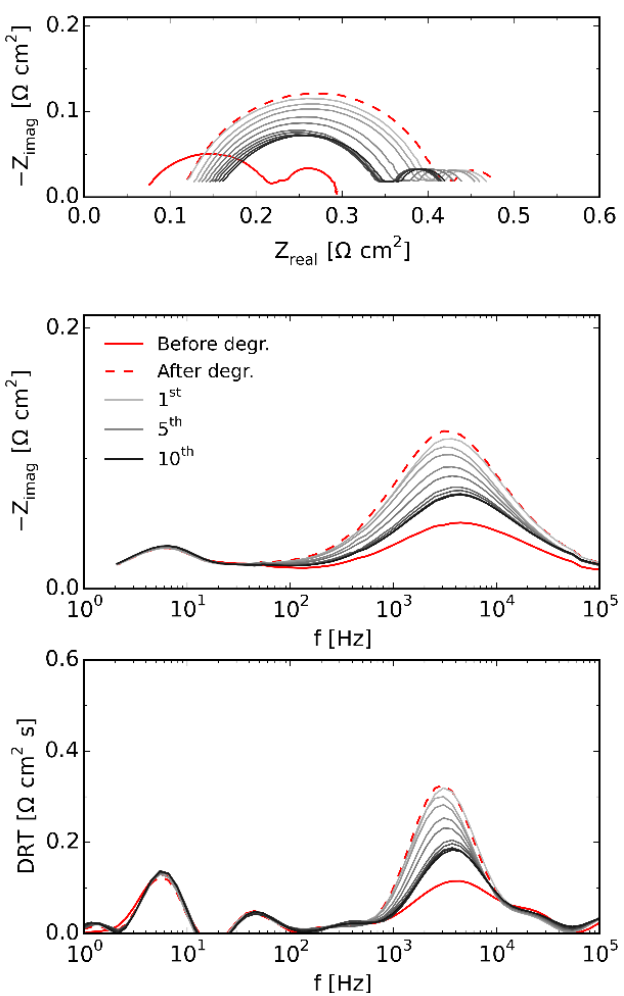

(d)
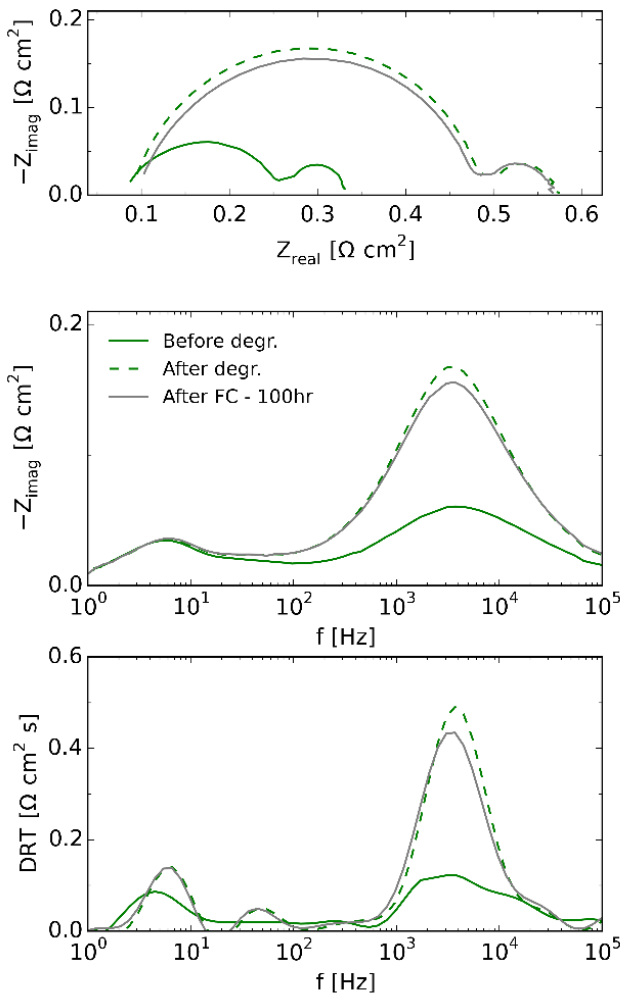

Figure 2: IS before, after degradation treatment and upon RCT cycles for Cell A (a), Cell B (b), Cell $\mathrm{C}$ (c) and Cell E (d) recorded at $\mathrm{OCV}, 700{ }^{\circ} \mathrm{C}, 20 \% \mathrm{H}_{2} \mathrm{O}$ in $\mathrm{H}_{2}$ to the fuel electrode. 
(a) Cell $\mathrm{A}-\mathrm{CO} / \mathrm{CO}_{2}$ degr.

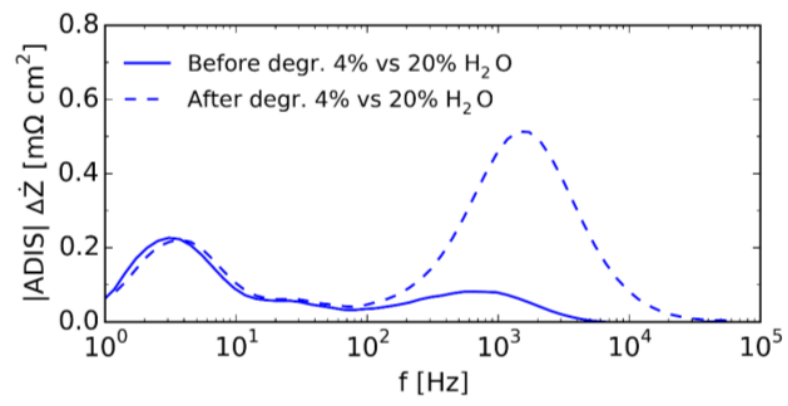

(b) Cell E - Electrolysis/oxidation degr.

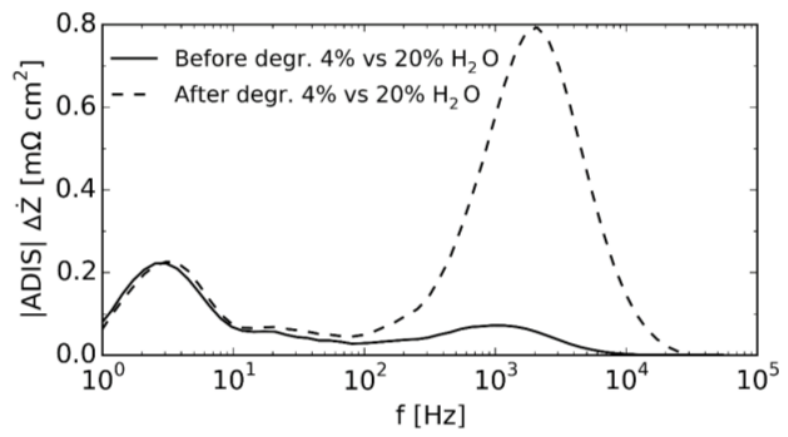

(c) Cell A - RCT activation

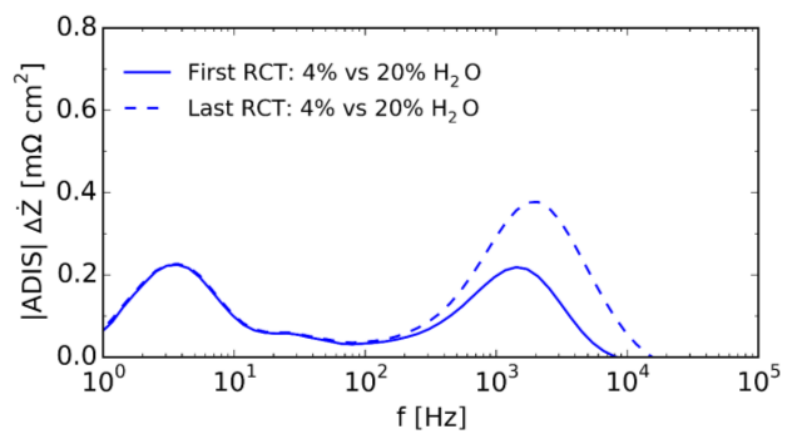

Figure 3: Analysis of differences in impedance spectra (ADIS) upon anode gas change (4\% and 20\% $\mathrm{H}_{2} \mathrm{O}$ in $\mathrm{H}_{2}$ ) before degradation treatment and after degradation treatment and after RCT treatment for test A (a) and test E (b), and ADIS upon fuel electrode gas change during RCT for cell A (c).

The breakdown of losses for the different IS was obtained via CNLS fitting the experimental data to an equivalent circuit model as described in section 2.3. An illustrative example of experimental data, simulated IS and the relative differences between experimental and simulated values for $\mathrm{Z}_{\text {real }}$ and $\mathrm{Z}_{\text {imag }}$ for the entire frequency range can be found for Cell $\mathrm{A}$ in 
"Supplementary Material" (Figure S3). As evident from these depicted IS, both models provide a satisfying agreement between experimental data and the simulated spectrum. The two models basically lead to the same overall value for fuel electrode resistance. The model applying the TLM for the impedance originating from the fuel electrode provides a superior description of the electrode (e.g. quantification of the length scale for the transmission line). However, the model employing two RQ-circuits to describe the electrochemical impedance contribution from the fuel electrode has in the work with experimental data in this work shown to be a more robust model and give slightly lower values for the relative residuals at high frequency compared to the simplified transmission line model (TLM). The quantitative results presented hereafter is therefore based on an equivalent model employing two RQ-circuits to quantify the electrochemical impedance contribution originating from the fuel electrode.

Table 3 summarizes the results from fitting of IS recoded for the different cells before and after degradation and after the last part of the activation via RCT (or constant galvanostatic fuel cell test for Cell D). To illustrate the development of the fuel electrode resistance ( $\mathrm{R}_{\text {fuel electr. }}$ ) upon each RCT cycle for the different cells; the fuel electrode resistance obtained from the IS after each RCT cycle is depicted in Figure 4. 
Table 3: Results from equivalent circuit modeling of IS recorded before and after degradation treatment and after last RCT (for Cell D after $100 \mathrm{~h}$ of fuel cell operation). The applied equivalent circuit model was described in the "Experimental" section and test specifications given in Table 1. For quality of fit and estimate of relative uncertainty, see Figure S3 in "Supplementary Material". Characteristic summit frequencies not listed in the table have the following values: $\mathrm{f}_{\mathrm{LSC} / \mathrm{CGO}}$ is $175-430 \mathrm{~Hz}, \mathrm{f}_{\text {Gas diff. }}$ is $30-75 \mathrm{~Hz}$ and $\mathrm{f}_{\text {Gas conv. }}$ is $5-8 \mathrm{~Hz}$.

\begin{tabular}{|c|c|c|c|c|c|c|c|c|c|c|c|c|c|c|c|}
\hline \multirow[b]{2}{*}{$\begin{array}{l}\text { Resistances in } \\
\Omega \mathrm{cm}^{2}\end{array}$} & \multicolumn{3}{|c|}{ Cell A } & \multicolumn{3}{|c|}{ Cell B } & \multicolumn{3}{|c|}{ Cell C } & \multicolumn{3}{|c|}{ Cell D } & \multicolumn{3}{|c|}{ Cell E } \\
\hline & $\begin{array}{c}\text { Before } \\
\text { degr. }\end{array}$ & $\begin{array}{l}\text { After } \\
\text { degr. }\end{array}$ & $\begin{array}{l}\text { After } \\
\text { RCT }\end{array}$ & $\begin{array}{c}\text { Before } \\
\text { degr. }\end{array}$ & $\begin{array}{l}\text { After } \\
\text { degr. }\end{array}$ & $\begin{array}{l}\text { After } \\
\text { RCT }\end{array}$ & $\begin{array}{c}\text { Before } \\
\text { degr. }\end{array}$ & $\begin{array}{l}\text { After } \\
\text { degr. }\end{array}$ & $\begin{array}{l}\text { After } \\
\text { RCT }\end{array}$ & $\begin{array}{l}\text { Before } \\
\text { degr. }\end{array}$ & $\begin{array}{l}\text { After } \\
\text { degr. }\end{array}$ & $\begin{array}{c}\text { After } \\
\text { FC test }\end{array}$ & $\begin{array}{c}\text { Before } \\
\text { degr. }\end{array}$ & $\begin{array}{l}\text { After } \\
\text { degr. }\end{array}$ & $\begin{array}{l}\text { After } \\
\text { RCT }\end{array}$ \\
\hline$\overline{\mathrm{R}_{\mathrm{s}}}$ & 0.092 & 0.093 & 0.116 & 0.070 & 0.111 & 0.147 & 0.069 & 0.073 & 0.089 & 0.082 & 0.089 & 0.096 & 0.077 & 0.086 & 0.113 \\
\hline $\mathrm{R}_{\text {ion }}$ & 0.042 & 0.035 & 0.063 & 0.020 & 0.040 & 0.047 & 0.012 & 0.016 & 0.094 & 0.036 & 0.020 & 0.057 & 0.040 & 0.024 & 0.091 \\
\hline$f_{\text {ion }}(\mathrm{kHz})$ & 12 & 10 & 18 & 21 & 14 & 25 & 25 & 25 & 12 & 18 & 19 & 10 & 16 & 8 & 30 \\
\hline $\mathrm{R}_{\mathrm{Ni} / Y S Z, \text { TPB }}$ & 0.138 & 0.353 & 0.092 & 0.127 & 0.261 & 0.155 & 0.248 & 0.262 & 0.088 & 0.137 & 0.375 & 0.325 & 0.113 & 0.403 & 0.137 \\
\hline $\mathrm{f}_{\mathrm{Ni} / \mathrm{YSZ}, \mathrm{TPB}}(\mathrm{kHz})$ & 2.46 & 3.19 & 12.3 & 3.89 & 3.24 & 4.03 & 2.13 & 3.23 & 7.64 & 3.18 & 3.41 & 3.21 & 3.81 & 4.50 & 16.8 \\
\hline $\mathrm{R}_{\text {fuel electr. }}$ & 0.180 & 0.388 & 0.155 & 0.147 & 0.301 & 0.203 & 0.259 & 0.278 & 0.181 & 0.173 & 0.394 & 0.382 & 0.153 & 0.427 & 0.228 \\
\hline $\mathrm{R}_{\mathrm{LSC/CGO}}{ }^{\text {a) }}$ & 0.001 & 0.001 & 0.010 & 0.002 & 0.002 & 0.004 & 0.026 & 0.053 & 0.032 & 0.003 & 0.002 & 0.001 & 0.011 & 0.029 & 0.017 \\
\hline $\mathrm{R}_{\text {Gas diff. }}$ & 0.014 & 0.015 & 0.009 & 0.014 & 0.014 & 0.013 & 0.008 & 0.002 & 0.012 & 0.015 & 0.017 & 0.018 & 0.008 & 0.002 & 0.006 \\
\hline $\mathrm{R}_{\text {Gas conv. }}$ & 0.064 & 0.065 & 0.066 & 0.061 & 0.056 & 0.060 & 0.039 & 0.046 & 0.042 & 0.062 & 0.067 & 0.068 & 0.061 & 0.062 & 0.065 \\
\hline
\end{tabular}

a) To support the characterization of the small impedance contribution from the oxygen electrodes; gas shift ADIS for the oxygen electrode during initial characterization as well as results from previous studies of symmetric cells were used to assist in qualified initial input for the CNLS fitting for the oxygen electrode contribution. Cell C was with a differently masked oxygen electrode

Page 18 of $\mathbf{3 9}$ 


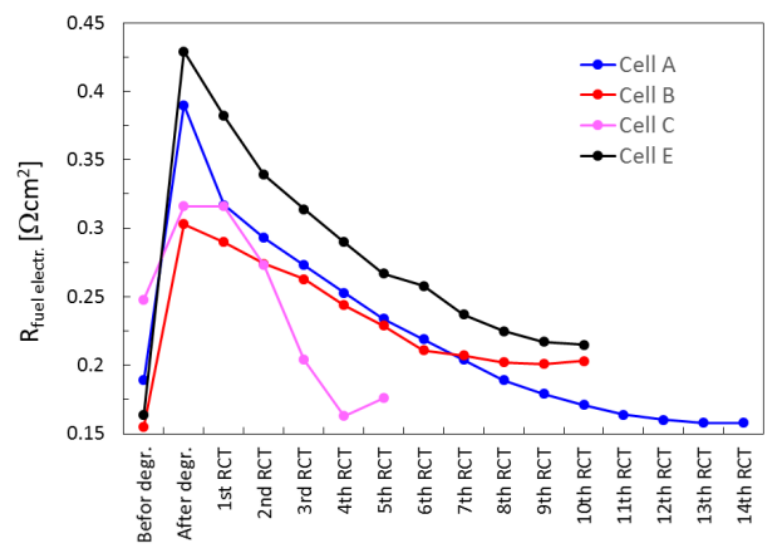

Figure 4: Fuel electrode resistances obtained from CNLS fitting an equivalent circuit model (see “Experimental”) to experimental IS for Cell A, B, C and E after each RCT cycle.

From the quantitative analysis of the IS, we observe that the initial choice of RCT cycles applying electrolysis current at dry conditions $\left(4 \% \mathrm{H}_{2} \mathrm{O}\right.$ in $\left.\mathrm{H}_{2}\right)$ for a duration of 10 seconds was a reasonable period. The longer electrolysis operation (stepping from 10 seconds to 50 seconds in steps of 10 seconds per RCT) did not have any additional positive effect on the fuel electrode resistance (Cell B). On the contrary, the development of the fuel electrode resistance for Cell $\mathrm{C}$ upon RCT applying increased current density (from $-1 \mathrm{~A} \cdot \mathrm{cm}^{-2}$ to $-3 \mathrm{~A} \cdot \mathrm{cm}^{-2}$ ) shows that a current density of approximately $-2 \mathrm{~A} \cdot \mathrm{cm}^{-2}$ will be advantageous to apply during RCT. A slight

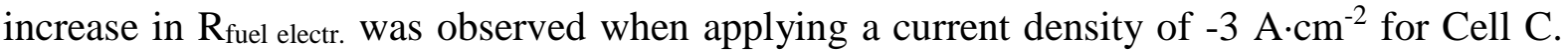
This could indicate that further reduction of the fuel electrode resistance cannot be obtained by increasing the electrolysis current density further during RCT.

While the RCT decrease the fuel electrode resistance, it also leads to an increase in ohmic resistance. An increase in $\mathrm{R}_{\mathrm{s}}$ between 23 and $48 \%$ was found for Cell A, B, D and E (Table 3). This is significantly more than the $14 \% \mathrm{R}_{\mathrm{s}}$ increase observed for Cell $\mathrm{C}$ during $100 \mathrm{~h}$ test at constant galvanostatic fuel cell operation at $1 \mathrm{~A} \cdot \mathrm{cm}^{-2}$. 
Lastly, when applying an equivalent circuit model using a TLM model we found changes in the transmission line length upon degradation and again upon re-activation. Qualitatively speaking such changes correspond to changes in the thickness of the active electrode layer in which the majority of the reactions takes place. No changes in transmission line length were observed when analyzing the IS from Cell D upon the $100 \mathrm{~h}$ galvanostatic fuel cell testing. As evident from the IS fit results (Table 3), the impedance from the LSC/CGO is not constant. However, the impedance attributed to this electrode in general only contributes less than $10 \%$ to the total polarization resistance both initially, after degradation and upon re-activation via RCT.

\subsection{Post-mortem analysis - scanning electron microscopy (SEM)}

\section{$\underline{\mathrm{Ni} \text { migration }}$}

Figure 5 shows examples of Ni/YSZ microstructures for different cell samples. For reference, Figure 5a shows a representative electrode structure from an edge piece of Cell A where the masked screen-printed oxygen electrode was not present, i.e., no current load was applied to this part of the cell. This piece is therefore considered a "reference" piece of the cell. From Figure 5b (Cell A), and even more pronounced in Figure 5c (Cell D), it is evident that Ni migration has occurred. Similar trends were observed for cell B and C, which were degraded in the same way as Cell A and D (fuel cell and electrolysis iV-curves in impure $\mathrm{CO} / \mathrm{CO}_{2}$ ). Table 4 gives an example of the quantification of Ni migration for Cell A based on the line intercept method for quantification of the Ni/YSZ microstructure [41]. The pore fraction for the reference cell was found to be only $20 \%$. However, based on cell manufacturing data and supplementary 3D reconstructions of similar fuel electrodes [10], the phase fractions can be expected to be Ni/YSZ/pore:31/47/22. Seen in this context the uncertainty on the phase fraction is roughly a few percentages for the SEM data summarized in Table 4. Even if the pore fraction 
is slightly underestimated and $\mathrm{Ni}$ overestimated in this analysis, it is clear that Ni migration has occurred for Cell A. This leads to a significantly more porous fuel electrode with an increase in porosity from $\sim 20 \%$ to $\sim 35 \%$. Besides the migration of $\mathrm{Ni}$ it is observed (Table 4 ) that $\mathrm{Ni}$ coarsen upon test while the YSZ phase does not seem affected by the RCT. For Cell E no significant Ni migration could be observed via visual inspection of SEM images in line with those depicted in Figure 5. A representative example of the Ni/YSZ electrode structure from Cell $\mathrm{E}$ is provided in Figure 5d. However, cell E shows a significant effect of delamination between the electrolyte and the fuel electrode. Re-call, that Cell E was not exposed to degradation via fuel cell and electrolysis $\mathrm{iV}$-curves in impure $\mathrm{CO} / \mathrm{CO}_{2}$. Cell $\mathrm{E}$ was degraded via harsh steam electrolysis conditions. This degradation led to fuel electrode resistance increase in the same range as obtained via the fuel cell and electrolysis iV-curves in impure $\mathrm{CO} / \mathrm{CO}_{2}$ 

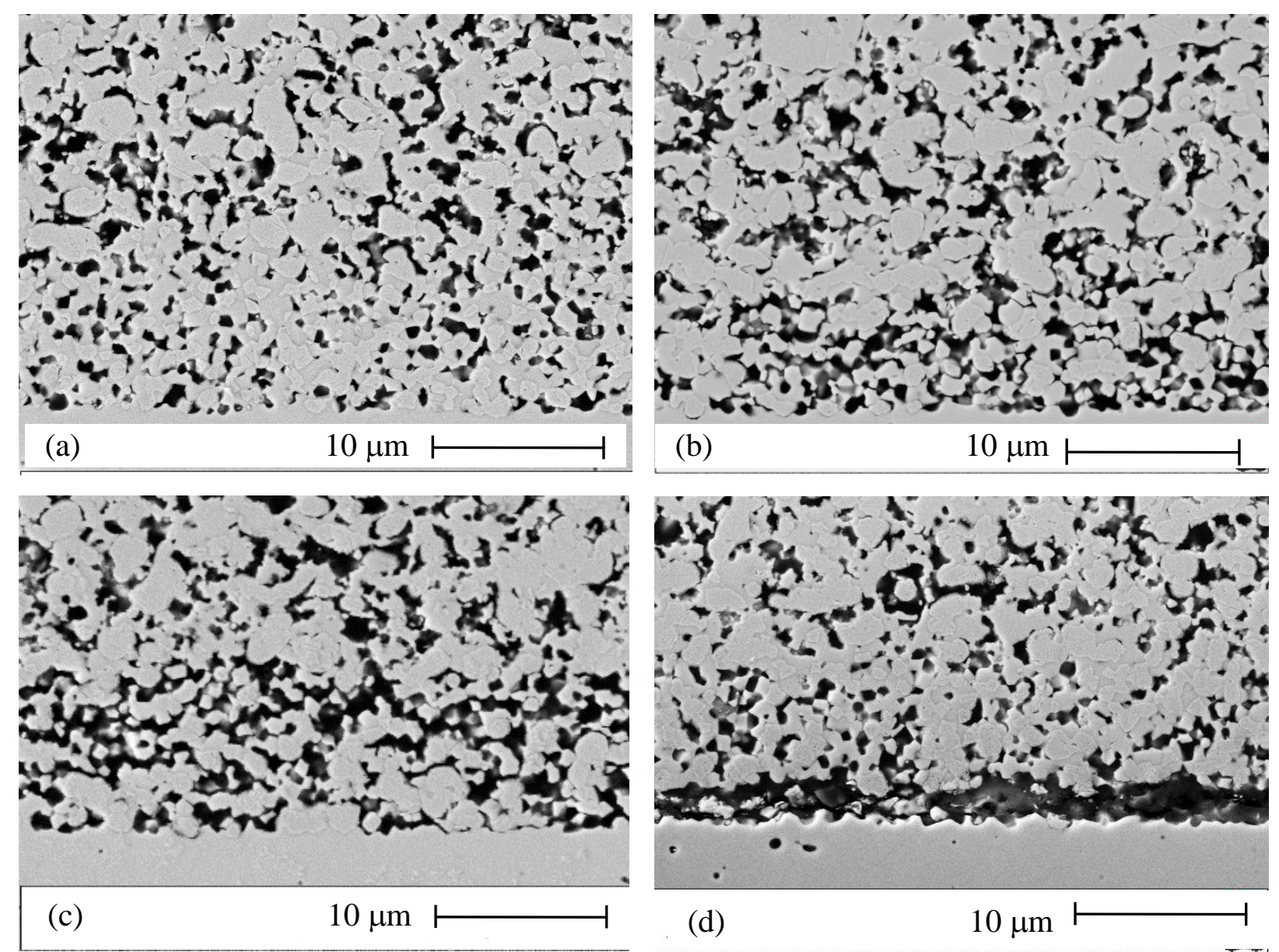

Figure 5: SEM images of electrolyte/fuel electrode interface to illustrate Ni network in the electrodes,

a) for a reference cell piece (no current applied), b) for Cell A, c) for Cell D and d) for Cell E. 
Table 4: Phase fractions, mean intercept lengths and number of particles per $1000 \mu \mathrm{m}$ intercept line for reference cell (Figure 5a) and from Cell A (Figure 5b) in a $2.5 \mu \mathrm{m}$ thick region of the fuel electrode close to the electrolyte. Several images similar to those in Figure 5 were used for the quantitative analysis to include measurements of at least 1000 particles for each phase per sample.

\begin{tabular}{|c|c|c|c|c|}
\hline & & $\begin{array}{c}\text { Phase fraction } \\
{[\%]}\end{array}$ & $\begin{array}{c}\text { Mean intercept } \\
\text { length }[\mu \mathrm{m}]\end{array}$ & $\begin{array}{c}\text { Particles per } 1000 \mu \mathrm{m} \\
\text { intercept length }\end{array}$ \\
\hline \multirow{3}{*}{$\begin{array}{l}\text { Ref. } \\
\text { cell }\end{array}$} & $\mathrm{Ni}$ & 35 & 0.84 & 352 \\
\hline & YSZ & 45 & 0.79 & 476 \\
\hline & Pore & 20 & 0.49 & 335 \\
\hline \multirow{3}{*}{ Cell A } & $\mathrm{Ni}$ & 23 & 0.97 & 193 \\
\hline & YSZ & 42 & 0.76 & 460 \\
\hline & Pore & 35 & 0.64 & 463 \\
\hline
\end{tabular}

\section{Weakening of the fuel electrode/electrolyte interface}

The fuel electrode/electrolyte interface was also investigated qualitatively by cross section SEM imaging of different cell pieces. Figure 6a shows a representative SEM image of the fuel electrode/electrolyte interface from an edge piece of Cell A where the masked screen-printed oxygen electrode was not present, i.e., no current load applied to this part of the cell. It is evident that - observed along centimeter long pieces of this interface - there is a proper adhesion between the fuel electrode and the electrolyte. The SEM sample preparation has not caused delamination between the fuel electrode and the electrolyte for the reference sample of Cell A. Figure $6 \mathrm{~b}$ shows an example of a region of Cell A (with oxygen electrode and therefore exposed to degradation treatment and subsequent RCT) where the fuel electrode is detached 
from the electrolyte. Such delamination can be found in some but not all parts of the investigated pieces from Cell A. Regions without delamination also occur (see Figure 5b). The deteriorated interface might not have been delaminated during testing and it is possible to attribute it to the sample preparation. However, the comparison of Figure $6 \mathrm{a}$ and Figure $6 \mathrm{~b}$ shows that this delamination cannot be only a result of SEM sample preparation. The observed regions of delaminated fuel electrode is therefore an indication of a weakened fuel electrode/electrolyte interface. It was possible to find regions of the cells where the fuel electrode had delaminated from the electrolyte for all cells except for Cell D. Notice that Cell D was the only cell not subjected to RCT. To illustrate that the fuel electrode/electrolyte interface for these specific cells, i.e. this cell batch, are not expected to be especially weak, a representative SEM image of a cell from the same tape of half-cell and same sintering but tested for 1 year at $700{ }^{\circ} \mathrm{C}$ and $0.5 \mathrm{~A} \cdot \mathrm{cm}^{-2}$ is shown in Figure $6 \mathrm{c}$. Here, a satisfying adhesion between the fuel electrode and electrolyte is present even after 1 year of fuel cell operation. 

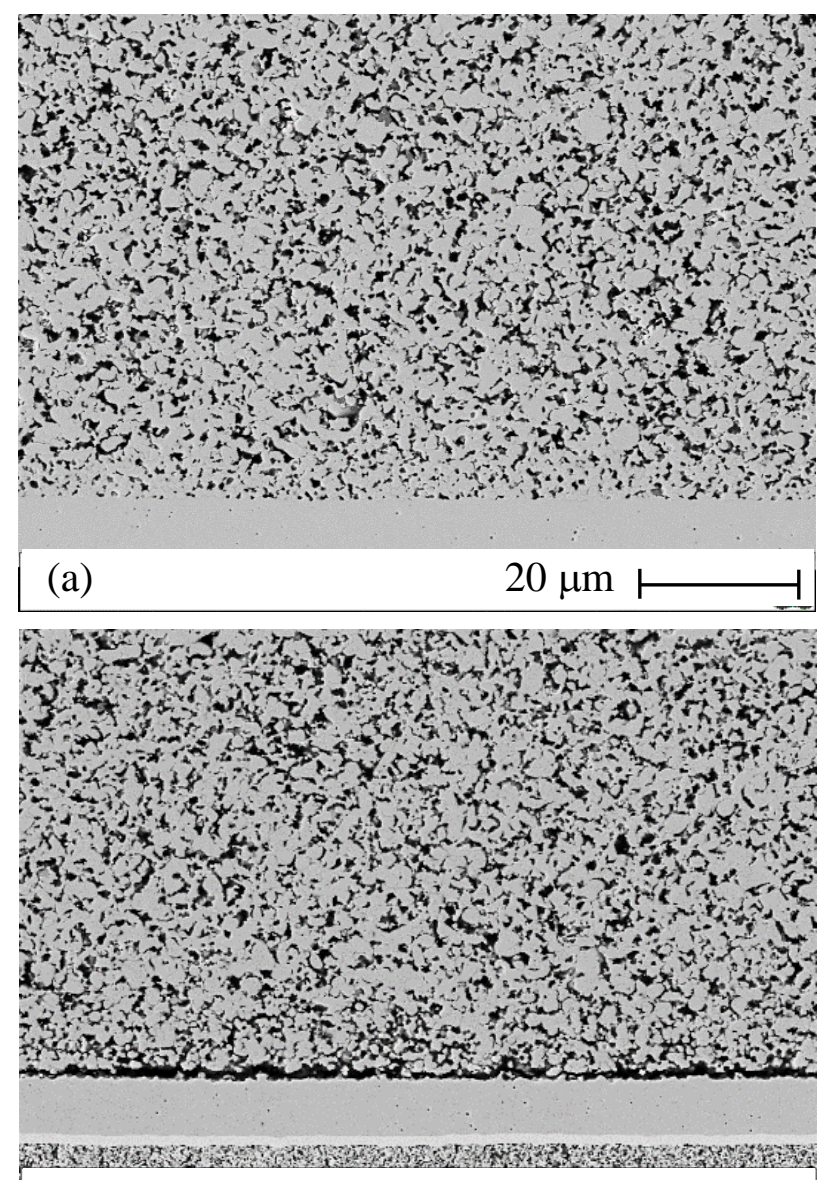

(b)

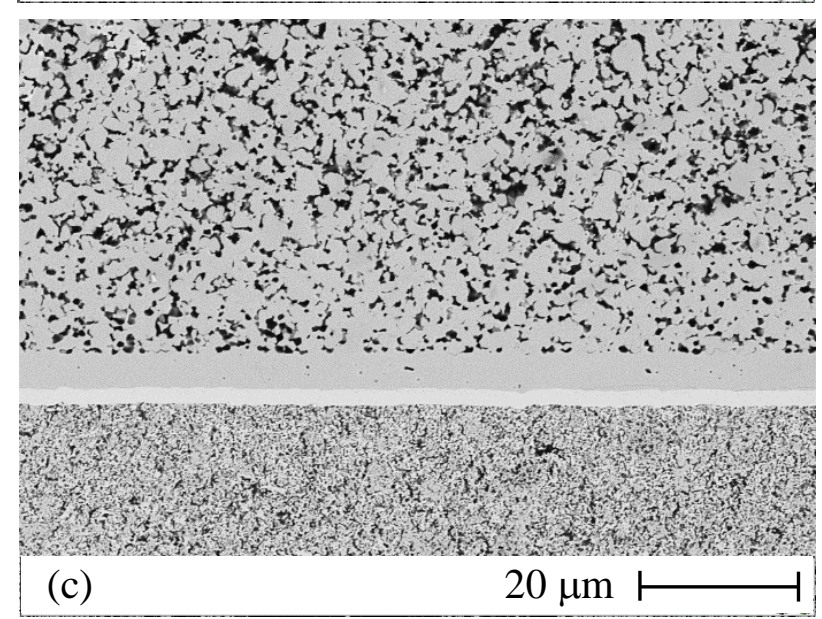

Figure 6: Illustration of the weakening of the electrolyte/fuel electrode interface. a) Reference sample of Cell A with no RCT applied. b) Weakened electrolyte/electrode due to RCT of Cell A. c) Cell from same production batch as Cell A, but tested for one year at $0.5 \mathrm{~A} \cdot \mathrm{cm}^{-2}$ and $700{ }^{\circ} \mathrm{C}$.

$\underline{\text { Nano-particles formed in fuel electrode structures }}$ 
Higher resolution SEM images reveal creation of nano-particles in the Ni/YSZ structures. It was possible to locate nano-structures in all cells except for cell D. Cell D was not exposed to RCT but activation of the fuel electrode was attempted via constant galvanostatic fuel cell operation. Figure 7 shows representative images from Cell A, D and E. Figure 7a shows a representative $\mathrm{Ni} / \mathrm{YSZ}$ electrode structure for Cell $\mathrm{A}$ in the region of the cell without oxygen electrode i.e. no current load was applied to this part of the fuel electrode. An intact Ni/YSZ electrode structure is observed in Figure $7 \mathrm{a}$ and particles appear very well adhered. Figure $7 \mathrm{~b}$ shows the electrode from Cell D from a piece with oxygen electrode. However, recall that Cell D was never exposed to RCT. This electrode structure (Figure $7 b$ ) rather resembles the reference piece from Cell A (Figure 7a) than the examples from Cell A and E (Figure 7c and Figure 7d) which also had oxygen electrodes and therefore exposed to RCT. In Figure 7c it is clear that nano-particles have been created in the fuel electrode structure of Cell A that was subjected to RCT for activation of the degraded fuel electrode. Figure $7 \mathrm{~d}$ shows the fuel electrode of Cell E. This cell was not exposed to the $\mathrm{CO} / \mathrm{CO}_{2}$ degradation process as Cell $\mathrm{A}$ but degraded via harsh $\mathrm{H}_{2} \mathrm{O}$ electrolysis operation. Subsequently Cell E was exposed to RCT for fuel electrode activation. Cell E (Figure 7d) shows similar examples of nano-particles as observed for Cell A (Figure 7c). The SEM findings depicted in Figure 7 provide a qualitative illustration of the effects of the RCT in the nano-to-micrometer scale for the fuel electrode microstructures. However, these SEM images do not quantify extent of formation of nanoparticles in the RCT treated cells nor do they provide the chemical compositions of these particles. It is expected that the composition of the nanoparticles is similar to that found in prior studies of this type of treatment [42]. However, detailed SEM/EDS and TEM/EDS are topics for future work. 

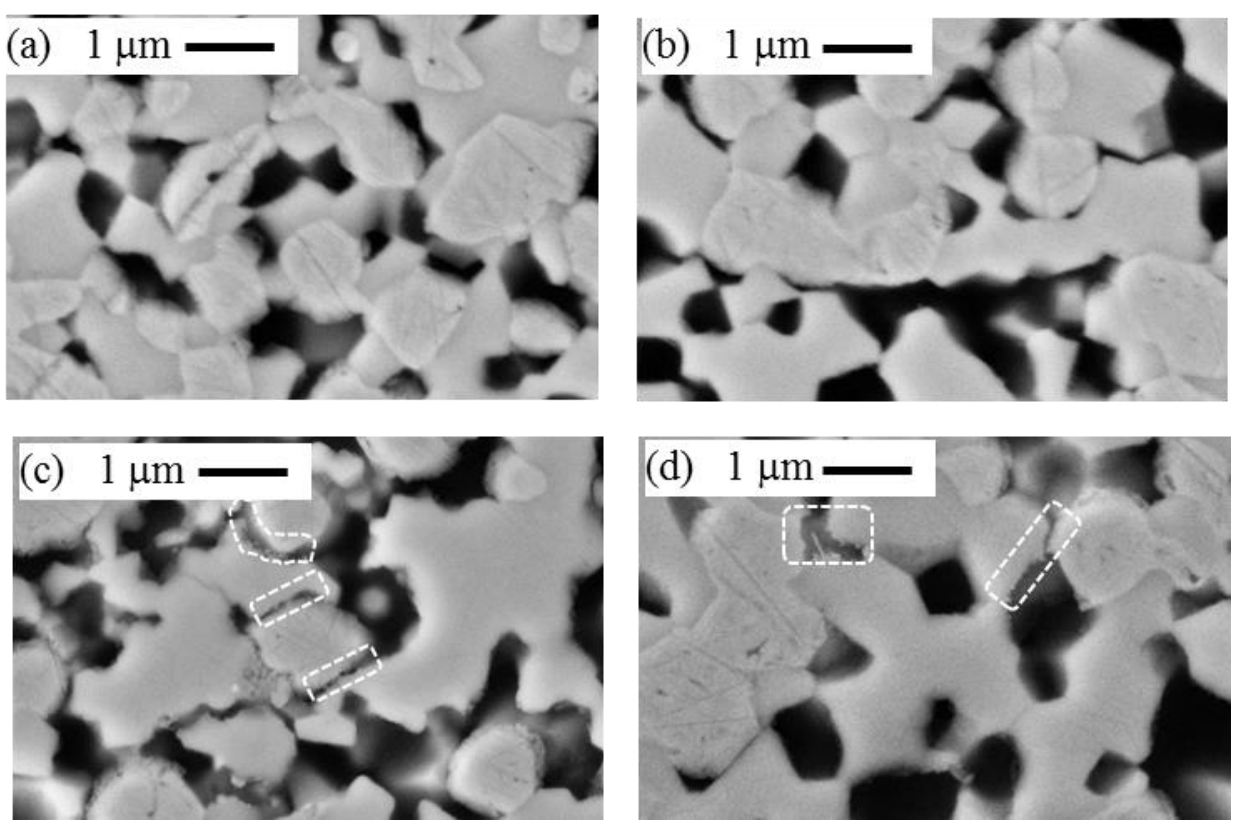

Figure 7: High magnification SEM of Ni/YSZ electrodes. White squares highlight nano-particles created in the fuel electrode structure. a) Reference piece (no current) from Cell A, b) Cell D with no RCT, only constant galvanostatic fuel cell operation after degradation, c) from Cell A subjected to RCT and d) from Cell E subjected to RCT, but no $\mathrm{CO} / \mathrm{CO}_{2}$ degradation treatment.

\section{Discussion}

\subsection{Degradation processes}

Figure 1 shows that a deliberate degradation of the fuel electrodes only was successfully obtained both via $\mathrm{iV}$-characterization in impure $\mathrm{CO} / \mathrm{CO}_{2}(\mathrm{Cell} \mathrm{A}, \mathrm{B}, \mathrm{C}$ and $\mathrm{D})$ and via harsh steam electrolysis iV-curves (Cell E). The ADIS analysis at different gas compositions to the fuel electrodes (Figure 3) qualitatively ensured that it was the fuel electrode that degraded and the characteristic frequency range for the loss in performance was as expected for a Ni/YSZ based fuel electrode [37]. From a scientific point of view, the applied methodology for degrading the fuel electrodes prior to the activation via RCT is not optimal. The quantities of impurities in the $\mathrm{CO} / \mathrm{CO}_{2}$ gas stream was not controlled but dependent on the specific gas 
supply of gasses. Even ppb level of impurities have been shown to influence the fuel electrode performance in electrolysis mode significantly $[11,14]$. It is therefore not surprising that the trend for the fuel electrode degradation of cell A, B, C and D is similar but the exact number for the fuel electrode resistance is not identical after degradation for each of the cells. However, from a practical and technological point of view this test procedure for fuel electrode degradation is appropriate, fast and relevant as impure gas streams are likely to occur at largescale facilities as well.

Figure 8 shows a sketch of the initial Ni/YSZ electrode microstructure to guide the discussion on the degradation and re-activation of the studied Ni/YSZ electrodes. The degradation treatments lead to roughly a doubling of $\mathrm{R}_{\mathrm{Ni} / \mathrm{YSZ} \text {,TPB }}$ for all the cells (Table 3 ). Meanwhile it can also be noted that the YSZ skeleton is stable (Table 4). The Ni particle coarsening is limited

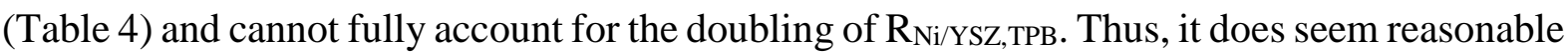
to assume that the majority of the degradation can be caused by impurities at the TPB as illustrated in Figure 8b. It is possible to remove surface adsorbed impurities simply by operating and characterization (e.g. $\mathrm{iV}$-curves) in pure $\mathrm{H}_{2} / \mathrm{H}_{2} \mathrm{O}$ [13], which will also be the case during RCT and the characterization along with that. This will likely leave weakened Ni-YSZ interfaces and such weakening of the Ni-YSZ interfaces can govern Ni migration as illustrated in Figure 8c [43]. This hypothesis is supported by the observed Ni migration (Figure 5b and Figure 5c) and quantified for Cell A in Table 4. The number of Ni particles for Cell A decreased more than $40 \%$ in the active fuel electrode layer. Notice also that the interfaces between Ni and YSZ particles in Cell E (no $\mathrm{CO}_{2} / \mathrm{CO}$ treatment) did not show similar weakening of interfaces nor Ni migration (Figure 5d). 


\subsection{RCT as fuel electrode activation processes}

The improvement of the fuel electrode performance through repeated RCT provides an in-situ, "in-time" and "in-position" Ni/YSZ electrode activation. It is highly attractive that the activation is done in-situ with no requirements for change of gas supply, cooling down, dismounting etc. The activation is also performed "in-time" in the sense that the activation process can be done in only few seconds to minutes depending on included characterization steps. Lastly, the RCT provides "in-place" formation of nano-particles in the sense that the nano-particles will form at and around the electrochemically active sites in the fuel electrode structure and not randomly in the fuel electrode and support layer structure as can e.g. be the case when applying infiltration of nano-particles.

For Cell A, B, C and E, the RCT lead to a significant decrease in $\mathrm{R}_{\mathrm{Ni} / \mathrm{YSZ} \text {,TPB }}$ (Table 3 and Figure 4). This is an indicator of increased TPB length for the RCT treated fuel electrodes. Figure 8d illustrates the expected microstructural changes in the fuel electrode upon degradation by impurities and subsequent re-activation via RCT. This illustration is based on the results of the analysis of the EIS and the post-mortem SEM imaging. For the fresh cell (Figure 8a) a given quantity of TPB will be available per electrode volume. Upon poisoning of the electrode by impurities, part of the TPB (in the range of half of it) are blocked and no longer available for the electrochemical reaction (red-shaded in Figure $8 b$ ). During the characterization at OCV impurities can possible desorb from surfaces and interfaces and lead to a weakening of the Ni/YSZ structure. However, and more importantly, the subsequent RCT lead to the formation of nano-particles (Figure 8d). In this sense, the term "re-activation" is not proper. It cannot be only the initial TPB that becomes available again upon RCT as it was possible to obtain $\mathrm{R}_{\text {fuel }}$ electr. after RCT that was lower than for the fresh cell. At least some additional TPB is formed in the structure upon RCT. The EIS results (Table 3) further support the fact that new TPB sites 
are formed during RCT as it is not only a decrease in $\mathrm{R}_{\mathrm{Ni} / \mathrm{YSZ} \text {,TPB }}$ that is attained but the RCT also lead to an increase in the summit frequency compared to the initial fresh state of the cell. Even though it is not possible to determine a direct quantitative correlation between observed nano-particles in the post-mortem SEM and the $\mathrm{R}_{\mathrm{Ni} / \mathrm{YSZ} \text {,TPB }}$ determined by EIS, the findings of nano-particles in the Ni/YSZ structure for the RCT treated cells (Figure 7) strongly supports the hypothesis sketched in Figure 8. Furthermore, the applied set-up for single cell testing in this work included fast-logging of cell voltage during RCT. The measured cell voltages during RCT reached $\sim 2.1 \mathrm{~V}$ during the $10 \mathrm{~s}$ (for test $\mathrm{D}$ up to $50 \mathrm{~s}$ ) of electrolysis operation. This verifies that conditions were present for zirconia reduction. Subsequent re-oxidation can then generate nano-particles in the active fuel electrode layer as also hypothesized by Irvine et al [18].

The results presented in Figure $7 \mathrm{c}$ and Figure $7 \mathrm{~d}$ do not provide data on the chemical composition of the newly formed structures in the RCT treated cells. Energy dispersive spectroscopy (EDS) on a bulk SEM sample is not optimal for such studies. However, the thorough SEM, TEM and EDS work by Chen et al showed that the nano-particles also formed upon high fuel electrode overpotential during electrolysis operation (though not done one purpose) were yttria containing zirconia particles [42]. We expect similar composition in this work and this phase is therefore expected to be ion conducting even though properties of these particles will hardly be identical to the "original" YSZ skeleton of the fuel electrode.

The work reported by Chen et al. [42] was obtained for full cells similar, but not identical, to the cells applied in this study. However, the microstructural effects were results of several hundreds of hours of operation. Their results are therefore not directly comparable with the fast RCT performed in this study. Based on the recent by Hansen et al. [44] of microstructural effect of strong cathodic polarization of a model Ni electrode it is plausible that the RCT lead to a 
kind of melting pot at the Ni-YSZ interface which then re-oxidizes to nano-particles and nanoporosities which was also suggested in the work by Irvine et al. [18]

Furthermore, network characteristics for these RCT-generated structures will play a role in their fuel electrode performance enhancing effect, but such study is not included in this work. Based on the electrochemical test results upon RCT, one can expect that at least some of the newly generated nano-particles are part of a percolating network.

Even for fuel electrode optimized S-O-A Ni/YSZ based SOC the charge transfer reaction resistance in the fuel electrode still constitute the largest share of the cell resistance [36]. The YSZ skeleton in S-o-A Ni/YSZ based SOC is reported to be very stable over thousands of hours of operation while Ni coarsen, see [45] and references herein. This could be used as an argument for aiming for creation of zirconia-based nano-particles rather than Ni nano-particles even though $\mathrm{Ni}$ nano-particles will also lead to performance increase. However, it is noteworthy that Myung et al. [20] reported rather stable galvanostatic fuel cell operation at 0.4 $\mathrm{A} \cdot \mathrm{cm}^{-2}$ and $700{ }^{\circ} \mathrm{C}$ for $\sim 100 \mathrm{~h}$ for the cell for which performance enhancement had been obtained by Ni exsolution from a perovskite "host". This indicate structure stability of their Ni nano-particles and similar - and longer - durability test should be conducted for the reverse current treated Ni/YSZ based SOC.

An attempt to make RCT activation for a non-degraded cell was conducted. However, five cycles of RCT did not lead to any significant improvement of the fuel electrode performance. This is believed to be because the formation of nano-particles at or in the near vicinity of the TPB via RCT requires a weakened interface or slight detachment between Ni particles and the YSZ backbone in the electrode structure (see illustration Figure 8c). 

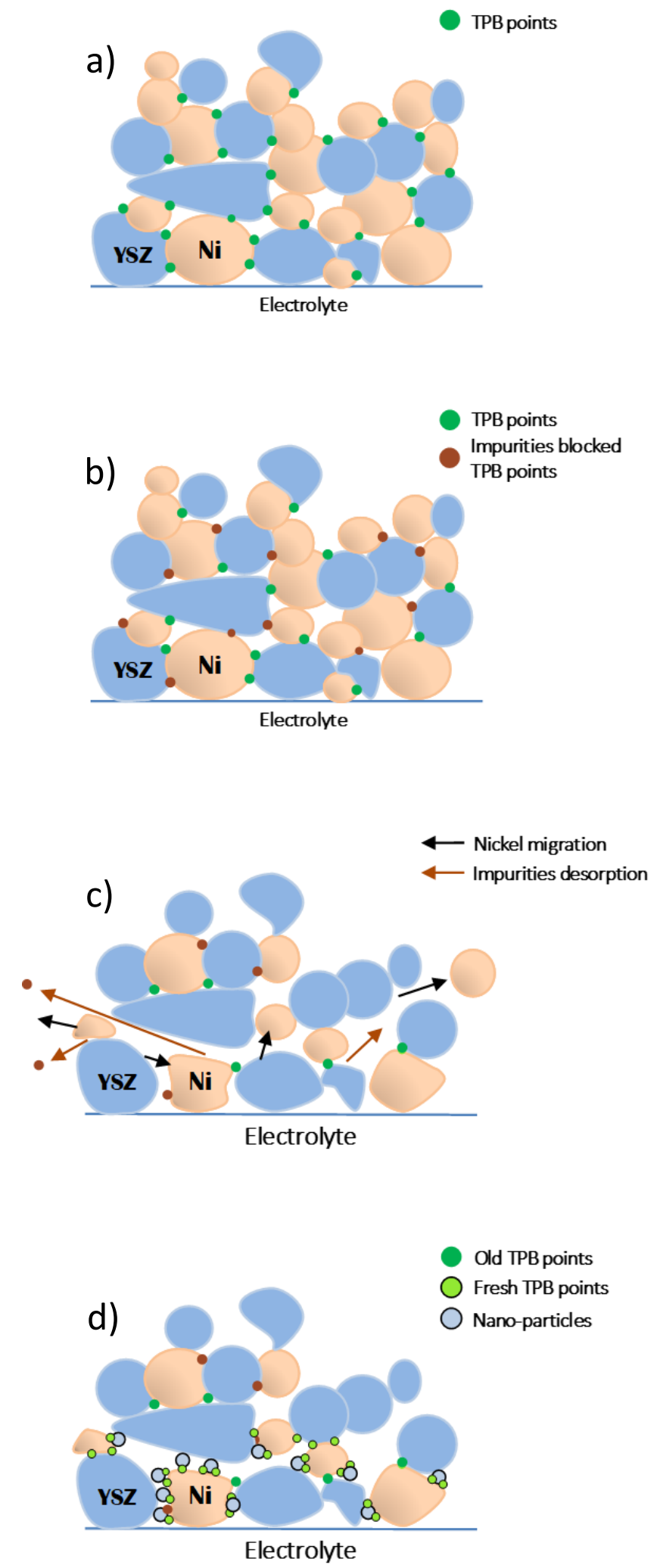

Figure 8: Illustration of microstructural changes in the fuel electrode from initial "fresh" state (a) to impurity degraded electrode (b) and upon Ni migration and impurity desorption (c) and after improving electrode performance via creation of nano-particles attained by RCT (d). 
The RCT comes with the drawback of a risk of delamination, or at least weakening of the electrode/electrolyte interface. This is supported by the observed increase in $R_{s}$, which takes place upon the several RCT cycles (Figure 1) performed on each cell in this study. In addition, we observed via SEM imaging regions with delamination of the fuel electrode from the electrolyte after RCT cycles. The results presented in this work cannot provide a complete description of the mechanism(s) underlying the weakening of the electrolyte/fuel electrode interface. Besides the nano-structured and nano-porous interfacial region formed by RCT, Mogensen et al. [43] discuss different mechanisms to describe the Ni morphology changes and $\mathrm{Ni}$ mobility and migration in the Ni/YSZ fuel electrodes that could also lead to a weakening of the electrolyte/electrode interface, as they will take place at the very interface towards the electrolyte as well.

The systematic monitoring of polarization resistances and $\mathrm{R}_{\mathrm{s}}$ upon RCT in this study highlights the importance of finding an optimum regarding number of RCT cycles, applied current density and time per cycle. This is to limit the $\mathrm{R}_{\mathrm{s}}$ increase while generating the most nano-particles. The formation of nano-particles enhances, and the electrochemical performance of the electrode. On the other hand, the RCT cycles should be tuned to avoid a too large and detrimental YSZ structural change due to the imposed redox cycle. Hence, the overall effect in

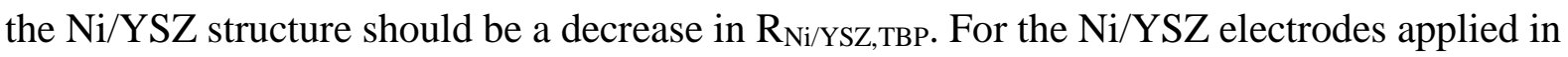
this study, we found an optimal RCT setting with current densities between -1 and $-2 \mathrm{~A} \cdot \mathrm{cm}^{-2}$. A hold-time of 10 seconds is sufficient and should be limited to approximately 10 cycles. In this study, the RCT led to high overpotential (reduction of the stabilized zirconia) for the $\mathrm{Ni} / Y S Z$ electrodes during electrolysis operation in $4 \% \mathrm{H}_{2} \mathrm{O}$ in $\mathrm{H}_{2}$. This is done only for short pulses of less than one minute each. This clearly induced changes at the nano-scale for the $\mathrm{Ni} /$ YSZ electrodes and led to an activation of degraded fuel electrodes. However, long-term 
exposure to conditions (high fuel electrode overpotential during electrolysis) for which postmortem analysis have shown formation of zirconia-based nano-particles have been reported to have a negative effect on the performance of the fuel electrode and an increase in $R_{s}[42,46]$. These studies showed that the zirconia-based nano-particles had a damaging effect on the NiNi network. Comparison of the work by Chen et al. and Tao et al. $[42,46]$ with the RCT activation of the fuel electrodes in this work illustrates how the formation of zirconia-based nano-particles in the Ni/YSZ fuel electrode structures can be either beneficial or detrimental, depending on the conditions and treatment time period [18].

Operating the cell at constant galvanostatic fuel cell conditions after the deliberate degradation of the Ni/YSZ electrode (Figure 2d) only led to very limited activation of the fuel electrode (Table 3). This in turn means that it is not the few minutes (approximately 10 minutes) at constant fuel cell test conditions before and after each RCT that lead to the observed Ni/YSZ electrode performance increase. Rather, the RCT (fast switch to electrolysis test conditions in dry $\mathrm{H}_{2}$ ) is responsible for the observed improved electrochemical performance of the fuel electrodes.

The possibility of re-activating the SOC Ni/YSZ-based electrode after degradation by applying an in-situ technique, such as the RCT investigated in this work, is a promising solution for extending the lifetime of state-of-the-art SOC toward the full commercial maturity. The proposed RCT technique studied in this work bring the advantages of being in-situ (i.e. no shutdown of the system is required) and fast. In principle, RCTs could be routinely applied. Nonetheless, future work should investigate the feasibility of the RCT on full-sized SOC stacks for which thermomechanical constraints are different from single cell test applied in this work.

\section{Conclusion}

From the results presented here, we conclude that: 
1) in-situ Ni/YSZ anode electrode (re-)activation is feasible by applying reverse current (electrolysis current) treatment pulses.

2) The reverse current treatment (RCT) technique is capable of producing active nanoparticles in the fuel electrode. This can (re-)activate the electrode performance by decreasing the charge transfer reaction resistance $\left(\mathrm{R}_{\mathrm{Ni} / \mathrm{YSZ}, \mathrm{TPB}}\right)$.

3) Detrimental effects on the fuel electrode half-cell are also observed when applying RCT cycles. Therefore, a tuning of RCT parameters (pulse current density, hold time, number of cycles) is required to avoid detrimental ohmic resistance increase, which offsets the beneficial activation connected to the nano-particles formation.

4) The application of the RCT lead to a reduction of the total fuel electrode resistance until an asymptotic trend was attained after which any further RCT pulse was not beneficial. Typically, 5-14 cycles of RCT are required to reach the highest fuel electrode performance.

5) The RCT application led to an increase in available TPB which in turn led to decreased electrode resistance. This was further documented by microstructural analysis (section 3.4 and 4.2) which showed that the microstructurally most affected part of the fuel electrode was the region closest to the electrolyte in which the nano-particles created via RCT were found.

6) Constant galvanostatic fuel cell operation of a degraded sister-cell did not lead to similar fuel electrode activation as the RCT did. Only a minimal fuel electrode activation could be observed after $100 \mathrm{~h}$ of galvanostatic fuel cell test.

\section{Acknowledgement}

The authors acknowledge colleagues at DTU Energy for fruitful discussions and technical assistance from especially Mr. H. Henriksen, Mrs. M. Davodi and Mrs. P. H. Nielsen is highly 
appreciated. Furthermore, the authors acknowledge financial support from the Danish ForskEL program via the project "Solid Oxide Fuel Cells for the Renewable Energy Transition" (SOFC4RET), project number 2014-1-12231.

\section{References}

[1] S.H. Jensen, P.H. Larsen, M. Mogensen, Int. J. Hydrogen Energy 32 (2007) 32533257.

[2] C. Graves, S.D. Ebbesen, M. Mogensen, Solid State Ionics 192 (2011) 398-403.

[3] E. Giglio, A. Lanzini, M. Santarelli, P. Leone, J. Energy Storage 1 (2015) 1-43.

[4] E. Giglio, A. Lanzini, M. Santarelli, P. Leone, J. Energy Storage 2 (2015) 64-79.

[5] M. Pozzo, A. Lanzini, M. Santarelli, Fuel 145 (2015) 39-49.

[6] C. Graves, S.D. Ebbesen, M. Mogensen, K.S. Lackner, Renew. Sustain. Energy Rev. 15 (2011) 1-23.

[7] M.A. Laguna-Bercero, J. Power Sources 203 (2012) 4-16.

[8] A. Lanzini, H. Madi, V. Chiodo, D. Papurello, S. Maisano, M. Santarelli, et al., Prog. Energy Combust. Sci. 61 (2017) 150-188.

[9] P.H. Larsen, K. Brodersen, Patent, US2008124602-A1; JP2008130568-A; EP1930974-A1; CN101242003-A; CA2611362-A1; KR2008047282-A; KR966845B1 (2008).

[10] K. Brodersen, A. Hauch, M. Chen, J. Hjelm, Patent WO2017029350 (2017).

[11] S.D. Ebbesen, C. Graves, A. Hauch, S.H. Jensen, M. Mogensen, J. Electrochem. Soc. 157 (2010) B1419.

[12] H. Madi, A. Lanzini, S. Diethelm, D. Papurello, J. Van herle, M. Lualdi, et al., J. 
Power Sources. 279 (2015) 460-471.

[13] A. Hauch, P.S. Jørgensen, K. Brodersen, M. Mogensen, J. Power Sources 196 (2011) $8931-8941$.

[14] S.D. Ebbesen, M. Mogensen, Electrolysis of carbon dioxide in Solid Oxide Electrolysis Cells, J. Power Sources 193 (2009) 349-358.

[15] P. Boldrin, E. Ruiz-Trejo, C. Tighe, K.-C. Chang, J. Darr, N.P. Brandon, ECS Trans. 68 (2015) 1219-1227.

[16] S.P. Jiang, Y. Ye, T. He, S.B. Ho, J. Power Sources 185 (2008) 179-182.

[17] R. Kiebach, P. Zielke, J.V.T. Høgh, K. Thydén, H.-J. Wang, R. Barford, et al., Fuel Cells 16 (2016) 80-88.

[18] J.T.S. Irvine, D. Neagu, M.C. Verbraeken, C. Chatzichristodoulou, C. Graves, M.B. Mogensen, Nat. Energy 1 (2016) 15014.

[19] D. Klotz, B. Butz, A. Leonide, J. Hayd, D. Gerthsen, E. Ivers-Tiffée, J. Electrochem. Soc. 158 (2011) B587.

[20] J. Myung, D. Neagu, D.N. Miller, J.T.S. Irvine, Nature (2016) 528-531.

[21] D. Klotz, J. Szasz, A. Weber, E. Ivers-Tiffee, ECS Trans. 45 (2012) 241-249.

[22] J. Hjelm, M. Søgaard, R. Knibbe, A. Hagen, M. Mogensen, ECS Trans. 13 (2008) 285-299.

[23] A. Hauch, C. Birkl, K. Brodersen, P.S. Jørgensen, Proceedings of the $10^{\text {th }}$ European Solid Oxide Fuel Cell Forum, Chapter 8 (2012) 62-71.

[24] S.H. Jensen, A. Hauch, P. V Hendriksen, M. Mogensen, J. Electrochem. Soc. 156 (2009) B757. 
[25] S.H. Jensen, Solid Oxide Electrolyser Cell, PhD Thesis, Technical University of Denmark, 2006.

[26] C. Graves, Ravdav data analysis software, Ravdav (2012) Ver 0.97.

[27] H. Schichlein, A.C. Muller, M. Voigts, A. Krugel, E. Ivers-Tiffee, J. Appl. Electrochem. 32 (2002) 875-882.

[28] V. Sonn, A. Leonide, E. Ivers-Tiffee, J. Electrochem. Soc. 155 (2008) B675-B679.

[29] A. Kromp, A. Leonide, A. Weber, E. Ivers-Tiffee, J. Electrochem. Soc. 158 (2011) B980-B986

[30] R. Mohammadi, M. Sogaard, T. Ramos, M. Ghassemi, M.B. Mogensen, Fuel Cells 14 (2014) 645-659.

[31] T. Ramos, J. Hjelm, M. Mogensen, J. Electrochem. Soc. 158 (2011) B814-B824.

[32] J. Nielsen, J. Hjelm, Electrochim. Acta. 115 (2014) 31-45.

[33] S. Primdahl, M. Mogensen, J. Electrochem. Soc. 146 (1999) 2827-2833.

[34] S. Primdahl, M. Mogensen, J. Electrochem. Soc. 145 (1998) 2431-2438.

[35] K. Thydén, Y.-L. Liu, J.B. Bilde-Sørensen, Solid State Ionics. 178 (2008) 1984-1989.

[36] A. Hauch, K. Brodersen, M. Chen, M.B. Mogensen, Solid State Ionics. 293 (2016) 2736.

[37] R. Barfod, M. Mogensen, T. Klemenso, A. Hagen, Y.L. Liu, P. V Hendriksen, J. Electrochem. Soc. 154 (2007) B371-B378.

[38] A. Hauch, M. Mogensen, Solid State Ionics 181 (2010) 745-753.

[39] A. Leonide, V. Sonn, A. Weber, E. Ivers-Tiffee, J. Electrochem. Soc. 155 (2008) B36-B41. 
[40] S.H. Jensen, A. Hauch, P.V. Hendriksen, M. Mogensen, N. Bonanos, T. Jacobsen, J. Electrochem. Soc. 154 (2007).

[41] E.E. Underwood, The Mathematical Foundation of Quantitative Stereology, Am. Soc. Test. Mater. 504 (1972) 3-38.

[42] M. Chen, Y.-L. Liu, J.J. Bentzen, W. Zhang, X. Sun, A. Hauch, et al., J. Electrochem. Soc. 160 (2013) F883-F891.

[43] M.B. Mogensen, A. Hauch, X. Sun, M. Chen, Y. Tao, S.D. Ebbesen, et al., Fuel Cells 17 (2017) 434-44.

[44] K.V. Hansen, M. Chen, T. Jacobsen, K. Thydén, S.B. Simonsen, S. Koch, et al., J. Electrochem. Soc. 163 (2016) F1217-F1227.

[45] M. Trini, P.S. Jørgensen, A. Hauch, M. Chen, P.V. Hendriksen, ECS Trans. 78 (2017) 3049-3064.

[46] Y. Tao, S.D. Ebbesen, M.B. Mogensen, J. Power Sources 328 (2016) 452-462. 